\title{
Article
}

\section{Developing the congruent academic through an integrated coaching approach}

\author{
Gillaspy, Emma
}

Available at http://clok.uclan.ac.uk/28141/

Gillaspy, Emma ORCID: 0000-0002-6725-3331 (2020) Developing the congruent academic through an integrated coaching approach. International Journal for Academic Development, 25 (3). pp. 285-289. ISSN 1360-144X

It is advisable to refer to the publisher's version if you intend to cite from the work. http://dx.doi.org/10.1080/1360144X.2019.1593175

For more information about UCLan's research in this area go to http://www.uclan.ac.uk/researchgroups/ and search for < name of research Group>.

For information about Research generally at UCLan please go to http://www.uclan.ac.uk/research/

All outputs in CLoK are protected by Intellectual Property Rights law, including Copyright law. Copyright, IPR and Moral Rights for the works on this site are retained by the individual authors and/or other copyright owners. Terms and conditions for use of this material are defined in the policies page.

\section{CLoK}

Central Lancashire online Knowledge www.clok.uclan.ac.uk

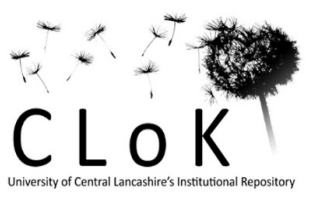




\title{
Developing the congruent academic through an integrated coaching approach
}

\author{
Gillaspy, Emma ${ }^{\mathrm{a} *}$
}

${ }^{a}$ Faculty of Health and Wellbeing, University of Central Lancashire, Preston, United Kingdom

Dr Emma Gillaspy, Senior Lecturer in Digital Learning, Brook Building BB424, Faculty of Health and Wellbeing, University of Central Lancashire, Preston, PR1 2HE, EGillaspy@uclan.ac.uk, +44 (0)1772 893717, @egillaspy, https://orcid.org/0000-00026725-3331, https://linkedin.com/in/emmagillaspy/

Dr Emma Gillaspy is an educator, academic developer and executive coach. Emma supports other educators in finding their own path to teaching excellence and works strategically to improve the student experience and update curricula. Emma's main interests include \#coachingHE (co-founder) \#creativeHE (co-host) \#LTHEchat \#experientiallearning \#heutagogy \#edtech \#socialmedia \#blendedlearning and \#curriculuminnovation 


\title{
Developing the congruent academic through an integrated coaching approach
}

\author{
Turbulent times in academia have resulted in a workforce that is stressed and \\ overworked. In this reflection on practice, I propose taking an integrated \\ coaching approach to academic development can support academics in making \\ sense of their whole congruent self and how their roles in teaching, research, \\ leading and living fit together. I explore three key elements of lifewide learning, \\ heutagogy and an asset-driven approach to coaching individuals and teams and \\ suggest future implications for the academic development community.
}

Keywords: coaching; resilience; lifewide learning; heutagogy; asset-driven

\section{Introduction}

With increasing pressures to improve the Higher Education (HE) student experience whilst growing numbers, alongside the ever-constant need to publish quality research, it is no surprise that academia is a stressful occupation (Grove, 2018; Persson, 2017). A study showing academic stress mainly originates from excessive workloads and low work-life balance, demonstrated that resilience was a protective factor which improved health outcomes and reduced the impact of such stressors (Johnson, Willis, \& Evans, 2018).

As academic developers, we are looking to develop resilient and self-aware academics who can thrive in this pressured environment. Conflicting pressures to develop as a facilitator, researcher and leader can result in ontological insecurity and imposter syndrome for academic staff (Knights \& Clarke, 2014; Parkman, 2016) and academic developers (Holmes \& Dea, 2012; Sutherland, 2015). Academic development is often separated into teaching, research, leadership and other institutional priorities which further increases the complexity for individuals to identify their individual developmental 
paths. Additional pressures such as year-round teaching and balancing work with home life paints a complex picture for academics to survive, let alone thrive.

From my own practice, I noticed that taking an integrated approach to individual and team coaching can have a marked impact on the whole academic, not just the individual elements of research, teaching and leadership. This integrated coaching approach incorporates three key features: lifewide learning, heutagogy and asset-driven coaching which are explored later in this paper. Coaching affords us the opportunity to empower the whole person, both within and outside work (Whitmore, 2009). Considering work and non-work factors, and the interplay between the two, are vital in developing resilience (Mak, Ng, \& Wong, 2011). Coaching positively impacts psychological factors such as reducing stress and improving wellbeing and resilience (Grover \& Furnham, 2016) and is therefore well suited to our current needs in HE.

Whilst neither one-on-one academic development and coaching are new concepts, I question if we are going deep enough into the whole reality for academics through our current developmental interventions. Are we supporting individuals in making sense of their congruent self and how their pieces of teaching, research, leading and living fit together? Could this new perspective enhance academic development practice and encourage us to develop the whole academic before specialising in specific areas such as teaching, research and leadership?

\section{Developing an integrated academic coaching approach}

By working with the whole person or team, we hope to empower individuals to take more control over their personal, professional and career development. Encouraging lifewide learning (Jackson, 2011) takes into account the interdependency of what is happening for the person within and outside the workplace. An appreciation of the potential for lifewide 
learning is the first feature of taking an integrated coaching approach to academic development. Coaching increases self-awareness and encourages analysis of lifewide behaviours, so individuals can take responsibility for positive action. In other words, they understand their ‘inner game’ (Gallwey, 1974) and can 'get out of their own way'. By understanding self, academics can identify which issues are within their sphere of influence or control, whilst acknowledging the cultural and structural constraints within which they operate. Team coaching is an effective developmental intervention however sometimes, working intensively with individuals is required to initiate breakthroughs to a deeper level of self-awareness. As you can see from the example below, behaviours and actions at home and at work are not mutually exclusive and by working with one element, we are also able to positively impact the other to enhance lifewide learning:

The coaching experience for me was a real ‘lightbulb’ moment. I felt I had been 'stuck' for a while (years in fact) trying to move along my writing and find my voice...(coaching) helped me realise that the problem was not so much a lack of skills, or time, or will, it ran deeper. We worked together to better understand how external factors were impacting on my work life and through several sessions I was able to better understand my self-sabotaging behaviours and the blocks I was putting in place to prevent me from achieving my goals... Since the coaching I am now much more aware of how my own behaviour puts obstacles in my way and am much better equipped to ask for help and to tackle issues in a more confident way... More importantly for me I feel as if I have found my 'voice' and am writing much more confidently. Lecturer and PhD Student

Have you observed this pattern - lifewide behaviours blocking perceived professional 'success' - in your own practice? How could we, as a sector, do more to leverage lifewide learning opportunities to positively impact academic development?

A second key feature of an integrated academic coaching approach is grounded in heutagogical principles where the learner decides their own path for development (Hase 
\& Kenyon, 2000) and takes relevant action (Whitmore, 2009). Heutagogy or 'selfdetermined' learning extends from andragogy (self-directed learning) with increased levels of learner maturity, challenge and autonomy (Hase \& Kenyon, 2013) which maps clearly to the environment needed for effective coaching (Blakey \& Day, 2012). The six heutagogical design elements outlined by Blaschke and Hase (2016) - explore; create; collaborate; connect; reflect and share - can be used to guide integrated coaching conversations to ensure academics are encouraged to fully explore their current reality and options for development, create a plan of action, collaborate and connect with peers, reflect on their progress and share their outcomes. Self-determined learning is gaining momentum and there are some examples of excellent practice in this area (Cochrane, Black, Lee, Narayan, \& Verswijvelen, 2013; Nerantzi \& Chatzidamianos, 2018). However there are few, if any, examples where heutagogy and coaching co-exist in a developmental intervention.

Adopting an asset-driven coaching style is the third key feature of an integrated academic coaching approach and focuses on the strengths of the individual. This arguably improves performance, reducing the stress which can be associated with a deficit model and leaves individuals feeling valued (Cooperrider, Whitney, \& Stavros, 2004). This approach supports people in stressful environments such as HE where the deficit model is all too apparent. By believing in the potential of the individual for positive change, we can look at challenging and often deep-rooted issues whilst maintaining a safe and supportive space. Reflecting on our own practice as academic developers, how often do we take an assets- versus deficits-driven approach? Could we do more to influence individuals and organisations to focus on strengths rather than weaknesses?

I notice that academics are more confident by the end of coaching and informal feedback suggests that it is these three features of integrated coaching practice that are 
key to this result. However, a significant challenge of this approach is that the academic(s) need to be ready and willing to reflect on their behaviours and take responsibility for change. This can be particularly challenging in team coaching situations where the individual motivation may clash with the direction in which the team wants to move. Integrating the three features of lifewide learning, heutagogy and an asset-driven approach to coaching (figure 1) provides the opportunity for us to develop the congruent academic and ensure our staff feel valued and supported in both their life and careers.

[figure 1 near here]

\section{Future implications for academic development}

- Increasing integrated development across the sector is vital. This is a widespread cultural issue however I hope that as academic developers, we can act as catalysts for change, increase collaborative working and reduce the conflicting pressures currently imposed on staff. For example, could we plan more collaborative staff induction activities across our teaching, research, technology enhanced learning, leadership and other academic development teams?

- Appreciating the value of lifewide learning would further acknowledge the interdependency of home and work lives in developing resilient academics. LygoBaker (2018) recently highlighted that bringing his lifewide interests and teaching practice together has enhanced his role. We could share more examples of good lifewide learning practice across our academic development communities.

- I will be further investigating the synergies between the elements of using an integrated coaching approach and the effect of these on individuals, teams and organisations. Have you observed any of these elements (lifewide, heutagogical or assets-driven approaches) in your own academic development practice? This 
may impact on our learning needs as academic developers in the future so we feel able to work confidently with lifewide, heutagogical and asset-driven development. In what other ways might we work together to develop the congruent, empowered academic in this turbulent HE landscape?

Acknowledgements: I would like to acknowledge all of the academics I have coached.

\section{References:}

Blakey, J., \& Day, I. (2012). Challenging coaching : going beyond traditional coaching to face the facts. Nicholas Brealey Publishing.

Blaschke, L. M., \& Hase, S. (2016). Heutagogy: a holistic framework for creating twenty-first-century self-determined learners. In The future of ubiquitous learning (pp. 25-40). Springer.

Cochrane, T., Black, B., Lee, M., Narayan, V., \& Verswijvelen, M. (2013). Rethinking e-learning support strategies. International Journal for Academic Development, 18(3), 276-293.

Cooperrider, D. L., Whitney, D., \& Stavros, J. M. (2004). Appreciative inquiry handbook: the first in a series of AI workbooks for leaders of change. (D. Whitney \& J. M. Stavros, Eds.). Berrett-Koehler,U.S.

Gallwey, W. T. (1974). The inner game of tennis. New York.

Green, W., \& Myatt, P. (2011). Telling tales: a narrative research study of the experiences of new international academic staff at an Australian university. International Journal for Academic Development, 16(1), 33-44.

Grove, J. (2018, July 6). Half of UK academics 'suffer stress-linked mental health problems.' Times Higher Education (THE). Retrieved from https://www.timeshighereducation.com/news/half-uk-academics-suffer-stresslinked-mental-health-problems

Grover, S., \& Furnham, A. (2016). Coaching as a Developmental Intervention in Organisations: A Systematic Review of Its Effectiveness and the Mechanisms Underlying It. PLoS ONE, 11(7), e0159137.

Hase, S., \& Kenyon, C. (2000). From Andragogy to Heutagogy. Ultibase RMIT. Retrieved from http://pandora.nla.gov.au/nphwb/20010220130000/http://ultibase.rmit.edu.au/Articles/dec00/hase2.htm

Hase, S., \& Kenyon, C. (2013). Self-determined learning: Heutagogy in action. A\&C Black.

Holmes, T., \& Dea, S. (2012). Mapping place and identity in academic development: a humanistic dialogue. International Journal for Academic Development, 17(3), 259-264.

Jackson, N. (2011). Learning for a complex world : a lifewide concept of learning, education and personal development. Authorhouse.

Johnson, S. J., Willis, S. M., \& Evans, J. (2018). An examination of stressors, strain, and resilience in academic and non-academic U.K. university job roles. International Journal of Stress Management.

Knights, D., \& Clarke, C. A. (2014). It's a Bittersweet Symphony, this Life: Fragile Academic Selves and Insecure Identities at Work. Organization Studies, 35(3), 
335-357.

Lygo-Baker, S. (2018). Did you hear the one about the stand-up, the preacher and the scriptwriter? | Teaching and Learning Conversations. Retrieved December 20, 2018, from https://tlcwebinars.wordpress.com/2018/12/10/did-you-hear-the-oneabout-the-stand-up-the-preacher-and-the-scriptwriter/

Mak, W. W. S., Ng, I. S. W., \& Wong, C. C. Y. (2011). Resilience: Enhancing wellbeing through the positive cognitive triad. Journal of Counseling Psychology, 58(4), 610-617.

Nerantzi, C., \& Chatzidamianos, G. (2018). Reflecting On Academic Development: A Dialogue About A FLEXible Journey. International Journal of Management and Applied Research, 5(2), 55-68. Retrieved from http://ijmar.org/v5n2/18-005.html

Parkman, A. (2016). The imposter phenomenon in higher education: Incidence and impact. Journal of Higher Education Theory and Practice, 16(1), 51.

Persson, R. S. (2017). Distress or satisfaction? : talent management in higher education worldwide. The International Centre for Innovation in Education (ICIE). Retrieved from http://www.divaportal.org/smash/record.jsf?pid=diva2\%3A1121027\&dswid=9522

Sutherland, K. A. (2015). Precarious but connected: the roles and identities of academic developers. International Journal for Academic Development, 20(3), 209-211.

Whitmore, J. (2009). Coaching for performance: GROWing human potential and purpose : the principles and practice of coaching and leadership.

Figure 1. Key features of an integrated approach to coaching for academic development 